\title{
Intrapreneurship and Innovation in Engineering Education
}

\author{
V.Thanikachalam \\ Executive Consultant in Engineering Education and HRD Chennai-600041 \\ vthani2025@gmail.com
}

\begin{abstract}
It is observed that around 1- $2 \%$ of the faculty membersin autonomous institutes usually take arisk in developing many innovative projects and programs for corporates and International Development Agencies (IDAs) by responding to letters of invitation or advertisements through abidding process. They utilize their talents, expertise and prepare high quality and cost effective projects which meet the stringent terms of references (TORs). These facultiesneedsempowermentand adelegationof administrators of the institutes but they are usually neglected in many institutes. Usually, there is an inordinate delay in forwarding thebid documents and providing with sufficient technical staff even though the revenue generated would meet all expenditures. Most of the innovations are due to intrapreneuers who are risk-takingfaculty members, and also think out of thebox and provide creative solutions. There is a need for supporting policy from the Chief Executing Officers (CEOs),Board of Governors, and government to encourage such outstanding ventures. Even though these institutes enjoy all types of autonomy but it is not passed on to the departments and to the faculty members. Institutes have to plan
\end{abstract}

\section{Dr.V.Thanikachalam}

Executive Consultant in Engineering Education and HRD Chennai-600041

vthani2025@gmail.com project specific policies, maintain separate accounts and distribute the gains as per the approved norms. Also,the fear of failing has to be removed from other faculty members besides giving the needed resources. Such initiatives would encourage more risk takers to undertake development activities, outreach programs and sponsored projects. Since the institutes have to contribute to the economy through providing aconducive environment for creating new and innovative products; the management has to take a lead.

Keywords : Intrapreneurship-Development PoliciesInternal Revenue Generation and Utilization. Introduction

\section{Introduction}

Well performing Indian engineering institutes like autonomous colleges, deemed to be universities, national institutes and Indian Institutes of Technologies are substantially contributing by undertaking many development projects for industries, governments, and International Development Agencies (IDAs). With high-quality faculty members with creative thinking, risk taking capability, they contributed to the development of improved industrial processes, produced new products and trained the executives of the industries. They also generated sufficient revenue through these activities. Most of the well-performingengineering institutes have established consultancy centers in the 1960s and nurtured the growth of these centers. However, the full potential of high performing faculty 
has not been put into action in many institutes which have been established by the governments or private edupreneurs.

\section{Objectives}

The following are the objectives of this paper to investigate the success factors, problems faced by the intrapreneurs, and the needed managerial changes in the institutes.

To assess the potential of well trained and educated engineering faculty in engineering institutes.

To identify the difficulties faced by the outstanding faculty members in undertaking externally funded projects from government departments, industries, and IDAs.

- To suggest remedial measures and interventions this could be approved by the Board of Governors of the engineering institutes.

Who are the Intrapreneurs?

The well-qualifiedfaculty members who evaluate their strengths, institutional resources, infrastructure, and the terms of reference for the projects offered by multinational corporations (MNCs) or International Development Agencies (IDAs) or Government Departments or National Project Executing Organizations and prepare technical or development proposals, and financial proposals. They send the bids through the institutes. Based on the CEOs approval, they negotiate with the external agencies who advertised the projects or who sent the letters of invitation and win the project. They systematically follow the rules and think out of thebox and present the best and cost effective solutions. Primarily they are risk takers. They also co-opt other competent faculty members and share all the documents but the funds are received by the institutes and remitted to the project account but they prepare total estimates, get the advances for execution and follow the norms and rules for spending the amount. They also complete the project as per the agreed terms and bring success and reputation to the institutes. The growth of excellence in industry-institute -partnership centers on such high-performing faculty.

\section{Consultancy Centers}

Most of the institutes allow the Heads of the Departments to use the workshop and laboratory resources for testing and providing consultancy to the public, government departments and industries. There are standards and norms for various testing services.

In some institutes, there would be a separate Consultancy Center which will coordinate with external organizations and the departments. The head of the consultancy center would receive inquiries and he will forward them to the concerned departments and the reply would be sent by him. Also, this consultancy center alone is authorized by the institute to correspond with the clients.

In some institutes, the Head of the consultancy post would be rotated among the senior professors. It is also designated as "Dean-Consultancy Works". The tenuremay vary from three years to five years.

Normally the deans would not directlyrespond to advertisements for undertaking consultancy works. Many governments provided guidelines for utilizing the gains of the consultancy works. AICTE has bought out separate guidelines for calculating the fees and utilizing the gains in 2000 and the same was published by the Indian Society for Technical Education's Newsletter.

Innovation CentersInnovation centers established by the engineering institutes would invite the national industries, and MNCs for utilizing the research findings, the patented processes and various innovations in planning, designing, manufacturing and maintaining the products. They also call for collaborative research on the industrial problems.Throughout the western world university,innovation centers could permit the industries to bring their employees and conduct their own confidential research and pay the rent to the university. The industry employees have greater contact with university researchers. The researchers are permitted to publish their research works without any restriction. Most of the large-scaleindustry sponsored projects provide five years funding which attracts many faculty members. University of California, Berkely permitted their faculty to have more freedom for publication.

\section{State of the Art}

Emily Abbott et al (2011) have brought out five essential elements of successfultwenty-first-century university corporate relation program. Since the intrapreneurship is well built into American educational system, there is no specific mention about 
this. Julio Pertuze et al (2010) listed best practices for industry-university collaboration. However, here also no mention about the university based intrapreneurs. Katherine Chudoba, Mary Beth Watson and Kevin Crowston (2012) listed innovation in academyindustry partnerships and measuring challenges to effective performance. Mark Gorden has recommended the commercializationuniversityowned technology. If the intrapreneurs are assisted by universities, then they would get more technology which can commercialize. NACRO Writing Team and Benchmarkking Committee (2011) listed five essential elements of a successful twenty-firstcenturyuniversity corporate relationships which are applicable to Indian engineering institutes also. Renu Khater(2013) described a case study on forging astrategic business partnership to develop the $21 \mathrm{st}-$ century workforce through an undergraduate petroleum engineering program at the University of Houston. Roger Geiger described the successful process of corporate-sponsored research at Penn State. U. S Senate Task Force emphasized universityindustry partnerships and brought out the desirable principles for large-scale collaborations. The Task Force suggests the freedom to the researchers and autonomy to the institutions. UIDP Projects (2013) brought out 10 case studies of high-return universityindustry collaborations. U. S Department of Commerce (2013) studied the process of creating the innovative and entrepreneurial university. All these indirectly focus on the competent and highperforming intrapreneurs whose creative thinking brings full success in sustaining effective industry university partnership which really gives rise to industrial leadership in the USA. In Texas, the University of Texas has fixed that about $25 \%$ of research expenditure has to be generated through industry sponsored research. Further, the institutions should enhance the ranks of the faculty so that they can undertake industry-sponsored research projects. Universities have to develop collaboration with the Regional innovation centers. The contribution of Bergquist and Pawlak (2008) in engaging six cultures and Hower A Mark (2012) in guidelines for keeping department's collaboration are presented in the next section.

\section{Research Methodology}

The research methodology centers on naturalistic evaluation. Four national institutes of technology, four national institutes of technical teachers training and research, four autonomous engineering colleges, and four deemed to be universities were considered. 16 senior faculty members have been selected to respond to the questionnaire. Questions were developed to assess the enabling factors and difficulties faced by the faculty members. Based on the feedback, the positive institutional factors are synthesized and presented below:

Institutional Factors that Enable Risk Taking Key Performers (Intrapreneurs)

The following factors enable the intrapreneurs:

- Vision of the institute which deliberately provides direction for taking many innovative programs and projects

- Freedom to use the institutional resources for externally funded projects

- Unrestricted distribution of letters of invitation (LOI) from the external agencies

- Freedom to respond to advertisements connected with development projects under various external agencies

- Empowerment based on the recognition of high performers/intrapreneurs

- Standard norms for estimating the cost of the projects/financial proposals

- Well-developed laboratories and workshops

- Availability of master craftsmen

- Internet facilities and modern library resources

- Encouragement for high achievement

- Delegation of authority to design the technical and financial proposals

- Conducive academic environment to form projectbased interdisciplinary teams of associates

- Excellent leadership at department and at institute levels

- Flexible norms for execution

- Evaluation of achievements of the team and recognition for the same

- Adequate exposure to the industrial development processes

- Industry focused training

- Well written rules and audit procedure

- Corpus funds for meeting the initial project related expenditure like submitting the bank drafts before the payment of initial advance

Interpersonal cooperation for sharing the project related works 
The patents are jointly owned by the intrapreneurs and the institute.

- Freedom to network with the institutes which have sufficient experts in the areas of the project

- Rules and regulations which provide detailed methods of estimating and spending on the project.

- Postgraduate departments would be highly useful for providing skills for preparing high-end consultancy programs.

- Some of theconsultancy works could be converted into research topics

- Doctoral students could be supported from the projects fund and they would become research associates.
The institutes permit to constitute multidisciplinary teams and the gains would be shared based on the contribution

\section{Problems Faced by the Intrapreneurs}

However, the intrapreneurs could have contributed very much many CEOs do not recognize them. They obstruct the work and make the entrepreneurssuffer a lot. Seeing these problems many capable faculty members do not take risk of developing any project.

The following problems are synthesized from the feedback and presented in Table. 1

\section{Table-1. Problems faced by the intraprenuers}

\begin{tabular}{|c|c|c|c|}
\hline $\begin{array}{l}\text { Description of the } \\
\text { problems faced }\end{array}$ & $\begin{array}{l}\text { Root cause analysis and } \\
\text { suggestions for } \\
\text { improvement }\end{array}$ & & $\begin{array}{l}\text { correct such intentional } \\
\text { deviations and corrupt } \\
\text { practices. }\end{array}$ \\
\hline $\begin{array}{l}\text { Intrapreneur has to } \\
\text { hand over the } \\
\text { project to an } \\
\text { unqualified } \\
\text { external } \\
\text { organization. }\end{array}$ & $\begin{array}{l}\text { Some CEOs order such } \\
\text { unethical acts, unless, there } \\
\text { is an evaluation of his acts } \\
\text { by the Boardof Governors } \\
\text { and possible corrections } \\
\text { through a resolution of the } \\
\text { Board. The Society's rules } \\
\text { do not provide scope for } \\
\text { improvement. Additional } \\
\text { rules are to be added by } \\
\text { the Board. }\end{array}$ & \multirow[t]{2}{*}{$\begin{array}{l}\text { Additional Project } \\
\text { work has to be } \\
\text { included based on } \\
\text { the user's needs } \\
\text { without any } \\
\text { increase in the } \\
\text { cost. }\end{array}$} & \multirow{2}{*}{$\begin{array}{l}\text { Many IDAs nominate one } \\
\text { of the user organizations to } \\
\text { approve the technical } \\
\text { proposal but some } \\
\text { representatives of the } \\
\text { client may force the project } \\
\text { leader to accept the } \\
\text { demands. When the project } \\
\text { authority prepared the } \\
\text { terms of reference and the } \\
\text { technical proposal has } \\
\text { been prepared without any } \\
\text { deviation, then the project } \\
\text { leader could prepare } \\
\text { thesupplementary } \\
\text { agreement and only when } \\
\text { it is approved, he can take } \\
\text { up additional areas of } \\
\text { development. }\end{array}$} \\
\hline \multirow[t]{2}{*}{$\begin{array}{l}\text { The letters of } \\
\text { invitation were not } \\
\text { circulated to the } \\
\text { faculty. }\end{array}$} & \multirow{2}{*}{$\begin{array}{l}\text { Some CEOs do this } \\
\text { systematically to sabotage } \\
\text { the work of the high } \\
\text { performing teams. The } \\
\text { Board has to evaluate the } \\
\text { misdeeds through an } \\
\text { annual evaluation of } \\
\text { administration and the } \\
\text { rules have to be formed } \\
\text { and compliance has to be } \\
\text { verified }\end{array}$} & & \\
\hline & & \multirow{2}{*}{$\begin{array}{l}\text { Letters of } \\
\text { Invitation has been } \\
\text { transmitted to the } \\
\text { unqualified } \\
\text { external agency. }\end{array}$} & \multirow{2}{*}{$\begin{array}{l}\text { Again a few corrupt CEOs } \\
\text { do this intentionally for } \\
\text { their benefit. Only Board } \\
\text { can rectify these acts by } \\
\text { constituting standing } \\
\text { committees. Such practices } \\
\text { are there in many } \\
\text { American Universities. }\end{array}$} \\
\hline \multirow[t]{2}{*}{$\begin{array}{l}\text { Unrelated external } \\
\text { members have to } \\
\text { be inducted into } \\
\text { the project. }\end{array}$} & \multirow{2}{*}{$\begin{array}{l}\text { Some CEOs order the } \\
\text { project executives to } \\
\text { accept such interventions } \\
\text { and pay the unrelated } \\
\text { external members. } \\
\text { Again the Board has to } \\
\text { collect the feedback from } \\
\text { the project executive and } \\
\text { take remedial measures. }\end{array}$} & & \\
\hline & & \multirow[t]{2}{*}{$\begin{array}{l}\text { The CEOs ordered } \\
\text { the project leaders } \\
\text { to stop responding } \\
\text { to the external } \\
\text { requests. }\end{array}$} & \multirow[t]{2}{*}{$\begin{array}{l}\text { Again this relates to the } \\
\text { unacceptable views of } \\
\text { incompetent CEOs. Only } \\
\text { the Board can take action. }\end{array}$} \\
\hline \multirow{3}{*}{$\begin{array}{l}\text { The cost estimate } \\
\text { has to be inflated } \\
\text { due to } \\
\text { competitor's } \\
\text { advice. }\end{array}$} & \multirow{3}{*}{$\begin{array}{l}\text { Some CEOs in } \\
\text { collaboration with the } \\
\text { competitors order such } \\
\text { unimaginable inflation so } \\
\text { that the institute loses the } \\
\text { project and the competitors } \\
\text { would gain the benefit. } \\
\text { In many circumstances, the } \\
\text { competitor may not have } \\
\text { acompetent team to } \\
\text { prepare successful bids. } \\
\text { The CEO would join the } \\
\text { external competitor and } \\
\text { corruption would be } \\
\text { institutionalized. The } \\
\text { Board has to evaluate and }\end{array}$} & & \\
\hline & & $\begin{array}{l}\text { The technical and } \\
\text { financial proposals } \\
\text { were withheld by } \\
\text { Administrative } \\
\text { Officers or the } \\
\text { project documents } \\
\text { are untraceable. }\end{array}$ & $\begin{array}{l}\text { This may be due to the } \\
\text { unethical instructions from } \\
\text { the CEOs only. }\end{array}$ \\
\hline & & $\begin{array}{l}\text { The Ministry } \\
\text { official insists that } \\
\text { he has to be } \\
\text { included in the } \\
\text { project team as an } \\
\text { expert. }\end{array}$ & $\begin{array}{l}\text { This is a strange way of } \\
\text { constraining the Institutes } \\
\text { and get unethical financial } \\
\text { gains. Such interventions } \\
\text { are more common in many } \\
\text { developing nations. Only } \\
\text { government can constrain } \\
\text { such actors. }\end{array}$ \\
\hline & & $\begin{array}{l}\text { The project gains } \\
\text { were not } \\
\text { distributed to the } \\
\text { project team. }\end{array}$ & $\begin{array}{l}\text { The CEOs would delay the } \\
\text { distribution and later } \\
\text { unethically withdraw the } \\
\text { amount and distribute } \\
\text { among certain office staff. } \\
\text { Criminal cases can be } \\
\text { filed. }\end{array}$ \\
\hline
\end{tabular}




\section{Barriers to Faculty Collaboration}

There are numerous barriers to form high performing teams and collaboration. Kezar and Lester (2009) identified the following factors:

- Professionalism of the faculty members

- Disciplines and departments of the proposed team members

- Paradigmatic differences among them

- Training underwent and socialization

Tenure of the faculty

- Reward system

- Bureaucratic and hierarchical administrative structures

- Clash between academic and administrative structures

Many such barriers could be eliminated by proper discussion and structured participation, welldesignedroles and proper distribution of the gains. The project leader has to respect the professional contribution of the diverse faculty members and eliminate conflicts.

Hower A Mark (2012) provided the following guidelines for deepening department collaboration:

- Promote a culture of shared leadership and responsibility for institutional goals.

- Develop a shared vision of the institute, and seek to build it in every moment and interaction.

- Actively reduce barriers to collaboration, and integrate of collaborative practices, into all important academic tasks and responsibilities.

- Create professional development opportunities, related to collaboration, including retreats, workshops, teaching circles, sabbaticals etc.

- Develop institutional rewards and recognition processes that support collaboration and individual initiative.

- Invite and support scholarship, exploring, documenting, and involving collaborative practices.

- Actively seek to expand the diversity of faculty mentors with a record of collaboration to support to new faculty members.

- Reflect periodically as an institute of the systems,processes, and relationships of the faculty members in the projects.
All these guidelines could be utilized to create more active faculty members who could become intrapreneurs.

Bergquist and Pawlak (2008) have brought the following six cultures of theacademy (Table.2).

Table- 2

\begin{tabular}{|l|l|}
\hline Culture & Focus of the culture \\
\hline Collegial & $\begin{array}{l}\text { Emphasized developing the } \\
\text { values and quality of character of } \\
\text { society's future leaders. }\end{array}$ \\
\hline Managerial & $\begin{array}{l}\text { Shares a commitment to serve } \\
\text { the needs of local commitment } \\
\text { especially providing access to } \\
\text { education to underserved populations. }\end{array}$ \\
\hline Developmenta & $\begin{array}{l}\text { Finds meaning primarily in the } \\
\text { creation of programs and activities } \\
\text { furthering the personal and professional } \\
\text { growth of all members of higher } \\
\text { education culture. }\end{array}$ \\
\hline Advocacy & $\begin{array}{l}\text { Finds meaning primarily in the } \\
\text { establishment of equitable and } \\
\text { egalitarian policies and procedures for } \\
\text { the distribution of resources and } \\
\text { benefits in the institution. }\end{array}$ \\
\hline Tangible & $\begin{array}{l}\text { Finds meaning in its roots, its } \\
\text { community, and its spiritual grounding. }\end{array}$ \\
\hline Virtual & $\begin{array}{l}\text { Answering the knowledge generation } \\
\text { and dissemination capacity of the } \\
\text { postmodern world. The virtual culture } \\
\text { values open, shared, responsive } \\
\text { educational systems and conceives of } \\
\text { the institution's purpose as connecting } \\
\text { to global and technological advances of } \\
\text { recent decades and responds to the } \\
\text { challenges facing higher education } \\
\text { including economic constraints and } \\
\text { declining public supports. }\end{array}$ \\
\hline
\end{tabular}


Intrapreneurs need more support which can be synthesized from the above six cultures. The CEOs have to nurture anappropriate supporting culture for extending the expertise of the faculty.

\section{Statewide Governing Boards}

Paul Lingenfelter, Richard Novak, and Richard Legon (2008) described the statewide governing boards and coordinating boards in 20 states of USA which are designed to be a 'built-in' connection of business and civic leaders to the higher education public policy dialogue, and to provide a permanent forum for higher education policy that is partially insulated from the give and take and discontinuities of the partisan political process. They provide a single, authoritative 'chain of command' from the board to the chief executive of every university in the state system. This formal power is its strength from the public accountability perspective; the ability to hire and fire can be an asset when seeking to make broad scale improvements. This method evaluates the actions of CEOs. The boards successfully balance institutional priorities with the public good, show a willingness to help lead and support strategic change by engaging in statewide, systemwide, at institutional planning, establishes expectations for accountability, assumes responsibility for results in the academic affairs of the university, and show the ability in balance engagement with an appropriate degree of detachment. Such statewide boards would bring success in all planning processes of the state engineering universities and state engineering colleges.

\section{Leadership challenges}

According to Paul Lingenfelter, Richard Novak and Richard Legon (2008), leadership challenge arises from uneven attention to board selection process. Appointing board members is the most direct way elected leaders can influence higher education governance. Paying more careful attention to selection is necessary for improving board capacity and performance. Board members can also become pawns in a high stake game between the legislature and the governor. Board seats can be doled out to less deserving executives on the basis of political connections or contributions. Building greater merit into the appointment process would minimize politics and help secure stronger and more effective boards. Hence, more care could be exercised in the selection of CEOs for the engineering institutes in India which will ensure more delegation to the intrapreneurs and enabling them to achieve more contribution to the consultancy.

\section{State Engineering Education Council}

Many states have recently established State Engineering Education Councils in India which will provide policy guidance to the engineering institutes. Also, this council can provide assistance in planning and implementindustry-focused services.

\section{Suggestions for corrections and improvements}

The Board of Governors could form standing committees on the industrial collaborations, assist the Intrapreneurs to bring more internal revenue. They can fix goals for sponsored research projects, new interdisciplinary graduate and postgraduate programs, the quantum of internal revenue, patents, publications, industry specific students assistantships, internships, and employment.The reputation of the institutes could be built easily through intrapreneurs and hence, they have to be encouraged but they have to be protected from harassment. Many CEOs do not even circulate the inquiries received from corporates governments. There should be an annual evaluation of the academic environment in the institutes and remedial measures could be taken. The CEOs could be trained on the motivational techniques and institutional development methods. It is essential to establish Industry-Institute-Partnership Centers with more freedom to take steps for bidding the development programs not only from the state and central governments but also from IDAs.

\section{Spin-Off Benefits}

The intrapreneuers usually develop industry relevant interdisciplinary and multidisciplinary graduate programs based on their expertise. Also, the engineering students would get industry specific skills and competencies and get excellent jobs. They are key performers in this area also. If the colleges do not establish interdisciplinary departments, it would be very difficult to implement such programs.

Also, the Intrapreneurs could bring more Industry Sponsored Dissertation and Research Works which could support many graduate students through assistantships and future employment. They could easily get very good exposure to the current industrial 
process. They could get very good training on the jobs. Many patents and publications could be developed through this process.

The well-performing institutes could network with other institutes and develop the faculty and utilize the resources and infrastructures. This would improve the regional competitiveness.

\section{Conclusion}

Under various institutional development and quality improvement programs, the faculty of engineering colleges has been trained in many cutting edges and emerging technologies. The project institutes have been designed to extend the expertise to the industries which would impact on the economy. The intrapreneurscould achieve very much under the knowledge-based economy only when they are provided with the needed delegationand empowerment. The Boards of Governors could take steps to improve the academic environment of the institutes by continuous improvement process.

\section{References}

Bergquist and Pawlak (2006) Engaging the Six Cultures of the Academy: Revised and Expanded Edition of the four Cultures of the Academy, San Francisco, CA: Jossey-Bass

Emily Abbott et al (2011)."Five Essential Elements of a Successful Twenty-First Century University Corporate Relation Program", Network of Academic Corporate Relations Officers Benchmarking Committee, USA.

Hower A. Mark (2012). Faculty Work: Moving Beyond the Paradox of Autonomy and Collaboration, Ph.D. Thesis in Leadership and Change, AuraAntioch University, http://aura.antioch.edu/etds/117

The institution ofEngineers Australia (1996)."Changing the Culture: Engineering Education into the Future", Report of the Review of Engineering Education, p 16.

Dr.James Gover and Dr. Paul Hurvay. "Educating 21st Century Engineers", IEEE-USA E-BOOKS, Washington DC, www.ieeeusa.org

Julio A.Pertuze et al. (2010). "Best Practices for Industry- University Collaboration", MIT Sloan Management Review, Summer- 2010, 51(4), 82-90.

Katherine Chudoba, Mary Beth Watson and Kevin Crowston (2012). "Innovation in Academic- Industry
Partnerships: Measuring Challenges to Effective Performance", TIM Submission-ID 17445, Boston, MA: Technology and Innovation Management Division, Annual Meeting of Academy of Management.

Kezaral and Lester(2009). "Organizing Higher Education for Collaboration: A Guide for Campus Leaders", San Francisco, CA: Jossey- Bass

Mark L. Gorden. University Controlled or Owned Technology: "The State of Commercialization and Recommendations",http://www.gbkecbaiigmenfmgj fcdgdpimamgkj/views/app.html

Merrill Schwartz, Richard Skinner and Zeddie Bowen (2009)"Faculty, Governing Boards, and Institutional Governance", TIAA-CREF Institute

Paul Lingenfelter, Richard Novak, and Richard Legon (2008)."Excellence at Scale- What is required of public leadership and governance in higher education?"Virginia, Charlottesville: Miller Center of Public Affairs, Association of Governing Boards of Universities and Colleges.

Pierre Gurdjian, Thomas Halbeisen and Kevin Lane (2014)"Why leadership-development programs fail ?"McKinseyQuarterly, www.mckinsey.com/insights/ leding-in_the 21 st_century/why_leadershipdevelopment_programs-fail

Randy L Conyers. "A Review of Leadership Theories and Possible Changes to Police Leadership", ht tp://ww w. chroome-extension // gbkeegbaigmenfmjfeledpimmgkj/views/app.html

Renu Khater (2013). "Forging Strategic Business Partnership to Develop the 21st Century Workforce, A Case Study of the University of Houston's Undergraduate Petroleum Engineering Program", The Business-Higher Education Forum. www.bhef.com

Roger L.Geiger. "Corporate Sponsored Research at Penn State: Report to the Office of the Vice President for Research", Center for the Study of Higher Education, the Pennsylvania State University. http://www.edpsu/eshe/working-papers/wp-1

Senate Task Force on University-Industry Partnerships."Principlesand guidelines for Large -Scale Collaborations between the University and Industry, Government and Foundations," USA.

Stephanie Bertels, James Gray, Omar RomoeroHemandez and Stave Hahn. "Six Challenges to Collaborative Research and Solutions for Addressing them". Network for Business

\section{JEE:}


sustainability, Ontario, Canada: Western University

UIDP Projects (2013) "10 Case Studies of HighReturn University-Industry Collaborations", USA

University of Newcastle (2004). "Bench Marks in Cultural Change in Engineering Education"

U.S Department of Commerce (2013) "The Innovative and Entrepreneurial University, Higher
Education, Innovation and Entrepreneurship in Focus", Office of Innovation and Entrepreneurship Development, Office of Innovation and Entrepreneurship Development. 